Valóságos könyvtár - könyvtári valóság. Könyvtár- és információtudományi tanulmányok 2016. Szerk. Kiszl Péter, Boda Gáborné Köntös Nelli.

Budapest, ELTE BTK Könyvtár- és Információtudományi Intézet. 2017. 161-168.

\title{
KÖNYVTÁRI E-BOOK: KÖLCSÖNZÉS ÉS/VAGY TERJESZTÉS?
}

\author{
KEREKES PÁL
}

ELTE BTK KITI, címzetes egyetemi docens

\begin{abstract}
ABSZTRAKT
Az elektronikus könyvek kölcsönzése angol és német nyelvterületen részévé vált a közkönyvtárak szolgáltatási kínálatának. Magyarországon az e-könyvek kölcsönzésére még nem alakult ki gyakorlat, ezzel szemben az ingyenes e-könyvek gyújteménye fejlődött ki. A szerzői joggal már nem védett múvek adatbázisa 12000 magyar nyelvű könyvet tartalmaz. A kortárs szerzőket talán a világon egyedülálló módon - szintén ingyenes digitális könyvtár szolgáltatja, s jelenleg 80 író életművéből áll a gyújtemény. További elektronikus könyveket szolgáltatnak ingyenesen a nagy egyetemi és megyei könyvtárak, valamint nagy magyar ingyenes könyvállományok találhatók a hajdan Magyarországhoz tartozó, ma önálló államok központi könyvtáraiban is. Ilyen jelentős szabad hozzáférésű digitális állomány megléte alapján felmerül a kérdés: érdemes lehet-e a magyar könyvtárak részére az elektronikus könyvek kölcsönzésének rendszerét kiépíteni? Vagy talán érdemesebb lenne a rendelkezésre álló kereteket az ingyenesség további lehetőségeinek megteremtésére fordítani? A tanulmány bemutatja a magyar nyelvű digitális könyvek ingyenes adatbázisait és elérési lehetőségeit.
\end{abstract}

\section{Az e-book nem informatikai, hanem könyvészeti fejlemény}

Az elektronikus könyv előképe nem a számítógép, nem a szövegszerkesztő alkalmazás, hanem az a textualitás, amely képes változni évezredekrôl évezredekre, évszázadokról évszázadokra, vagy napjainkban, akár évtizedenként. A hardvergyártók, szoftver-programozók csak készítői, nem feltalálói az elektronikus irodalomnak. A szöveg papírtól független megjelenítésének bőven voltak előzményei az elmúlt száz évben. Az avantgárd mozgalmak kísérletei, majd később a hangköltészet, legutóbbi időkben a digitális hordozókra rögzített tartalom mixek már a vers és regény virtualizációja felé való haladás állomásaiként értelmezhetők.

Az a szöveg, amely digitalizált és szabványosan formatizált, bármely képernyőn, illetve akár ipari vagy reklám-célú elektronikus felszínen kísérheti az olvasót. Az elektronikus szövegben a tipográfiai újítások helyett az optikai innováció járul hozzá a mondanivaló spiritualizációjához. A tartalom kibővül hypertext utalásokkal. A karakterláncból való internetes hivatkozások beillesztése vizuálisan is jelzi az elágazásokat más tartalomkombinációk irányába. Az olvasó maga végezhet befogadást segítő formai műveleteket: a betűméretek változtathatók, a sortávolság állítható, a szövegtömbök jobbra-balra-középre rendezhetők; a kijelölésekkel perszonalizálható a könyv. Kindle e-könyv-olvasó esetében az adott szövegrész alatt halványan felsejlik a mások által tett 


\section{KEREKES PÁL}

kiemelések nagyságrendje; az X-Ray értelmező valósággal preparálja a szöveget: a zárójeles boxban egyes szavak fölött megjelenik annak magyarázata. Könyv-applikáció esetében a tartalom interaktív betoldásokkal (játék, dinamikus grafikonok), multimédiás alkotórészekkel (videó, hangbejátszás, animáció), informatikai szolgáltatásokkal (helymeghatározás) tágul ki.

A fentiek alapján megállapítható: a digitális text nem egy kötött módszertanhoz, a nyomdászat képességeihez determinált kommunikáció, hanem egy változékony, sokféle alakiságot, több egymásra épült dimenziót rejtő, médiatizált publikáció.

A még alig néhány éves, de sok zsurnalisztikai leegyszerűsítéssel terhelt, valójában rendkívül bonyolult és összetett digitális kultúra témakörében az e-könyvészet határainak kijelölése különösen fontos lehet.

Véleményem szerint az e-könyvészet tárgykörébe tartozik minden olyan elektronikus tartalom, amely a könyvszerúség formai jegyeit viseli, elsősorban természetesen maga az e-könyv. Az e-könyv, illetve az elektronikus könyvszerűség ismertetőjegyei: döntően szövegalapú publikáció, ha időlegesen is, de lezárt karaktersorozat. Szerkesztett, ellenőrzött, befejezett mű, amelynek van címoldala, tartalomjegyzéke, fejezetbeosztása, amelynek szerves részei más intertextes elemek, mint lábjegyzetek, mutatók, függelékek, grafikai kiegészítők, úgymint ábrák, táblázatok, illusztrációk. Az elektronikus könyv lehet interaktív és tartalmazhat nem szöveges elemeket, amelyeket különböző formátumokban jeleníthet meg (többek között audio- és videofájlok, infografika, animáció) funkcionálisan kapcsolódva az elsődleges tartalomhoz. Ugyanannak a szöveges tartalomnak a gépi felolvastatása is az e-könyvészet termináljához kapcsolható, csakúgy, mint több más határterület, mint például a Print on Demand (nyomtatás igény szerint) konstrukció, vagy a számítógépes programmal kreált irodalmi alkotás, és az egyre népszerűbb hangoskönyv, illetve a videókönyv. A könyv-applikáció mint új fejlemény a maga informatikai effekt-rendszerével (zene, kép, hang, játék, film stb.) jelenleg a leginkább fejlődés alatt álló e-könyvészeti forma. Az e-tankönyv is szövegműfajként tanulmányozható, még akkor is, ha fokozatosan besorolódik az e-tananyag kategóriába, ami egyre inkább prezentációs és tesztelő-visszakérdező oktatói felületekben jelenítődik meg. Az e-könyvészet folyamatosan vizsgálja és elemzi az olyan új könyvmúfaji meghatározásokat, mint a következők (a fogalmakat itt nem értelmezzük helyhiány miatt, csak jelezzük mûködési elnevezésüket): okoskönyv, intelligens könyv, médiakönyv, digitális könyv, hibrid könyv, blogkönyv, interaktív könyv, virtuális könyv, könyv-applikáció. Az e-könyvészet kutatási tartományába tartozik az e-könyv felépítmény analízise, tehát az e-könyv kereskedelmi vagy non-profit intézményi, szolgáltatói rendszerének figyelemmel kísérése (e-könyvkiadók, e-könyv-forgalmazók, e-könyvtárak, e-könyv-archívumok és közhasznú projektek, e-könyv-adatbázisok, e-könyv-eszközfejlesztők, globális, meghatározó e-könyv szereplők - Amazon, Kobo, Google, Apple - könyvpolitikai aktivitása). Az e-könyv platformjai (ePub, Kindle formátum) és az azok közötti átjárás módszertana is e-könyvészeti bázistéma. Speciális területe az e-könyvészetnek az elektronikus publikáláshoz kapcsolódó szerzői jogok ismerete, elismertetése. Kifejlődőben 
van, és egyre nagyobb lendülettel zajlik az e-könyvészeti kutatások keretében a digitális szövegtermékeket rendszeresen olvasók (gyakran használt szóval: felhasználók) szövegelsajátítási viselkedésének, befogadói magatartásának feltérképezése.

A folyóiratok, online irodalmi portálok nem tartoznak az e-book fogalomkörébe, függetlenül attól, hogy egy adott mű későbbi létmódja eredetileg ezekhez a médiumokhoz is kapcsolható.

Az e-könyvészet definitív fogalmi elhatárolása (vagy annak kísérlete) nélkül fennáll a veszélye annak, hogy a konvergáló múfajok fogyasztóért vívott harcában a könyvszerűség értékrendjét és tradicionális értékközvetítő szerepét a képpel, videóval dúsított, gyors-szövegekre alapozott mixek, médiahibridek, meghatározhatatlan identitású digicsomagok vehetik át. Ma mindent e-booknak minősítenek, ami letölthető, monitoron követhető. A szövegkupeckedést (free könyv-állományokból kimásolt mûvek árusítása forintért vagy valutáért) nem vonhatjuk egy megítélés alá a hagyományos könyvkultúrából szervesen kifejlődött digitális könyvszármazékokkal. A tartalom-nagykereskedés (játékok, alkalmazások, zenék, filmek között a hátsó polcra helyezett könyvek forgalmazása az úgynevezett applikációs áruházakban, mint például: Google play, Windows store) nem az e-könyv természetes prezentációs felülete; ez az online fejlemény nem vezethető le a könyvértékesítés hagyományaiból. A szkennelt szövegek, szövegtöredékek disztribúciója (alkalmi portálok kalózállományai, sikerkönyvek terjesztése megosztó oldalakon) vagy a globális portálokra csempészett textverziók offshore forgalmazása (nemzetközi self-publishing portálokra - pl. Smashwords - való kihelyezés, start-up hátterű könyvelőfizetéses oldalakra - Scribd, Oyster - illegális tartalmak feltöltése) az e-könyvészet keretein belül a negatív jelenségek meglétére figyelmeztetnek. A digitális tartalomáradat járulékos mellékhatásaként jellemezhető könyv- és szerzőellenesség globális módozatai (kiadói tiltott adatgyüjtés az olvasóról, szérializálás, fejezetenkénti könyvforgalmazás, reklám ellenében szabaddá tett könyvrészletek stb.) elleni tudományos és oktatói szintű fellépés elkerülhetetlen. Ugyanebbe az etikai csomagba tartozik a magyar nyelvű könyvszerű tartalmak, e-book verziók nyomon követése a nemzetközi digitális tereken a minőség és szöveghűség, valamint a jogszerűség védelme érdekében. Hazai e-könyvészeti aktivitást sürget a globális portálokon kínált magyar nyelvű e-könyvek hátrányos megkülönböztetésének észrevételezése és lehetséges korrekciójának előmozdítása. (Például az Amazon magyar nyelvű e-könyvet nem forgalmaz, vagy a szerzői nevek és könyvcímek helyesírásának problémája a kizárólag angol ábécét használó forgalmazóknál.)

\section{E-book helyzetkép könyvtári szempontból}

A jövő könyvtárosának - de ez igaz más szakmákra is, és különösképp a tanári hivatásra az informatika nyújtotta lehetôségek következtében olyan könyves világgal kell szembenéznie, amelyben az alapművek, legyen az szépirodalom vagy referensz munka (lexikon, enciklopédia) ingyenesen elérhetôk, szabadon és korlátozás nélkül letölthetők: az olvasó helyétől függetlenül, a maga választotta időbeosztására építve. Egy oktató-tudásgazdálkodó szakember számára ez gyökeresen más helyzet, mint a korábbi művelődési feltételrendszer. 


\section{KEREKES PÁL}

Az elektronikus tartalomszolgáltatás, és benne kitüntetetten az elektronikus könyv jórészt hozzájárult ahhoz, hogy az átfogó statisztikák szerint ma a könyvtárak egyre népszerúbbek. Az internet nem a fizikailag létező könyvtárak kiüresedéséhez vezetett, hanem éppen fordítva: egyre többen látogatják élő valóságban is a könyves intézményeket, attól függetlenül, hogy a virtuális gyűjtemények kínálata is egyre bővül. A könyv extra költségráfordítás nélkül - sokkal inkább, mint valaha - komótosan elérhető kultúrcikké vált. Az információforrások szabadon buzognak. A világháló által biztosított lehetőségek révén a könyvtári szolgáltatások már nem csupán a valós, hanem a digitális térben is megjelennek, és e lehetőségek kiszabadították a könyvtárak működését a tér és idő korlátozta keretekből.

\section{E-könyvtári projektek}

Michael Hart, a legenda szerint az első e-könyv kreátora - és aki talán az egyetlen, aki nem gazdagodott meg az internet nagy feltalálói közül - már a múlt század hetvenes éveiben azt gondolta: az e-könyvnek nem lehet más célja, mint hogy mindenki maga rendelkezhessen otthon szinte az egész világirodalommal. Ez gyakorlatilag meg is valósult. Hart megalkotta a PC (Personal Computer) mintájára a PL (Personal Library) fogalmát. Sokszor idézett kijelentése volt: „A tanulás önmaga jutalma. Nem tudnék ennél többet mondani.”

Kézzelfoghatóbb axiómája azonban a következő: „Két dolog van a világon, ami tényleg ingyenes és kimerithetetlenül rendelkezésre áll: a levegö, amit beszivunk és a Gutenberg-projekt könyvei." (Angol eredetiben: „There are two things in the world that are truly, totally free with an endless supply. The air we breathe and the texts on Project Gutenberg.")

Csakhogy igaz-e ez az állítás? Igazabb, mint valaha. Csak a magyar nyelvet véve figyelembe, kijelenthető: könyvek tízezrei érhetők el ingyenesen. A Magyar Elektronikus Könyvtár (MEK) a klasszikus magyar irodalmat, a Digitális Irodalmi Akadémia (DIA) a széles értelemben vett kortárs irodalmat szolgáltatja költségmentesen. Ide számíthatók még a megyei és városi könyvtárak digitális gyűjteményei is. Jelentős a globális free könyvtári projektek magyar állománya, itt elsősorban a Gutenberg Projektet érdemes említeni. Az olvasó eszköz (e-reader) lehet bármilyen digitális gépezet: asztali PC, notebook, táblagép, telefon és természetesen e-könyv-olvasó is.

Az ingyenesség végtelen tartományába tartozik még két sajátos e-könyves terjesztési, kínálati módozat:

1. Eltérően a hagyományos nyomtatott kiadvány-forgalmazástól, az e-könyv áruházak nagy számban kínálnak szabad letöltésű könyveket is. Ezek a könyvek lehetnek eleve ingyenesnek tervezett könyvek, de lehetnek akcióban ingyenessé tett művek. Gyakori jelenség, hogy klasszikusokat, keresett kötelező olvasmányokat szabadítanak fel az árprés alól. Nem ritka, hogy népszerú szerzők kedvelt, magasan forgalomképes regényeit teszik a főlapra időleges ingyenes elérhetôséget nyújtva. Az iTunes, vagy a Kobo külön listázza a free magyar könyveket. Az Amazon szabad állománya is jelentős, bár nincs közöttük magyar nyelvű. A magyar e-book-plázák nagy hányada is nyújt ingyenes készleteket. A Publio, a Multimédiapláza, a Book and Walk elhatárolt menüsorokban ajánlja free állományát. Az Alexandra külön 
online olvasófelületen porciózza ki a szabadon lapozható múveket. Az ingyenes letöltés feltétele többnyire a regisztráció, ami nem jár az olvasó részéről költséggel.

2. Az ingyenesség másik formája a könyvekbe való szabad betekintés. Kétségtelen, hogy ez is csak a regisztrált olvasók részére nyújtott szolgáltatás, de a regisztrációnak nincs semmiféle korlátja, sem földrajzi, sem anyagi értelemben - tehát az érdeklődő költségmentesen regisztrálhat a világ legnagyobb könyvesboltjaiba. Konkrétan mit jelent ez a „beleolvasási opció”, vagy gyakran csak „minta” fogalom alatt futó lehetőség? Nem kevesebbet, mint hogy a könyv adott részébe - többnyire tíz-húsz százalékába - beleolvashat a látogató. Ez gyakran a könyv első része, ám - az Amazonnál például - lehet úgynevezett „meglepetés oldal” is, azaz a könyv más fejezetei is teljes egészében feltárulkoznak. Nem túlzás tehát azt mondani, hogy a teljes magyar és a széles földkerekség idegen nyelvű friss könyvválasztékába belepillanthatunk, méghozzá nagyon jelentős terjedelemben. Nincs vásárlási kötelezettség a mintaként letöltött könyvek után. Szakkönyv esetén ez a lehetőség szinte nem eléggé értékelhető, főleg ha hozzászámítjuk, hogy a tartalomjegyzék birtoklásáig feltétlenül eljutunk, ami sok esetben vízválasztó a vásárlás szempontjából. Nagy vitát váltott ki a könyvtárakban, hogy az elektronikus katalógusban (függetlenül attól, hogy nyomtatott vagy digitális múrôl van szó) megadható-e az adott könyv Amazon elérhetősége is; az olvasónak opciót nyújtva arra, hogy a könyv jelentős hányadát megismerhesse a könyvtári rendszeren keresztül.

\section{Az e-könyv és a könyvtár (nemzetközi kitekintés)}

Az e-könyv elterjedésének kezdeti szakaszán már megjelent az a törekvés, hogy lehetővé váljon az elektronikus szövegművek könyvtári kölcsönzése is. Maga a megvalósítás nehezen indult, még az is felmerült, hogy hajótörést szenved az e-book könyvtári szolgáltatásának lehetôsége. Egyszerűen nem állt rendelkezésre olyan üzleti modell, amelynek alapján a kiadók a könyvtárak részére forgalmazhatták volna a digitális múveket. A jogtulajdonosok félelme az volt, hogy a könyvtárak nem tudják megvédeni az elektronikus tartalmat, és emiatt az olvasók kezén rövidesen a könyvkalózok zsákmányává válik minden könyvtári e-könyv, ezzel megakadályozva a kereskedelmi értékesítést. A könyvtárak részéről viszont az tûnt kezelhetetlennek, hogy a megvásárolt e-könyv nem kerül az intézmény birtokába, a fizetés ellenében csak egy felhasználási jog illeti meg a vásárlót. Hosszas tárgyalások után, miután minden résztvevő fél érdeke megegyezett, illetve az olvasói igény is erôsen megjelent, végül sikerült múködőképes konstrukciót találni.

Ennek lényege egyszerűen az, hogy a könyvkiadó és a könyvtár közé beépül egy további szereplő: a könyvtári e-könyv szolgáltató. Ez a teljes egészében profit alapú vállalkozás vásárolja meg és szolgáltatja az olvasónak az e-könyvet a könyvtár informatikai közremúködése nélkül. A könyvtár „csak” a jogosultságot adja az olvasónak, hogy a kívánt múhöz hozzáférjen. Gyakorlatilag tehát a könyv nem kerül a könyvtár birtokába, csak a könyv licencét vásárolja meg, és ezt adja tovább az olvasónak meghatározott időre. A könyvtár vagy egyenkénti használat után fizet a könyvtári szolgáltatónak, vagy 


\section{KEREKES PÁL}

csomaglicencet vásárol. Ez utóbbi azt jelenti, hogy megvesz adott számú használatot (általában 25-30 kölcsönzést), majd ha kifogy a keretből, újra megveszi a csomagot. Természetesen az olvasás tekintetében nemcsak e-könyv-olvasó eszköz jöhet számításba, valamennyi olvasásra alkalmas szerkezet (asztali gép, notebook stb.) megfelel. A könyvet nem kell a lejártakor visszavinni, újra dokumentálni a visszaadást: határidőre megszűnik a mủ olvashatósága (kinyithatósága). Az USA-ban e téren az Overdrive könyvtári üzleti szolgáltató a legnagyobb szereplő, de tevékenykednek a piacon más cégek is. Német nyelvterületen az ekz.bibliotheksservice médiacsoport üzemeltet önállóan menedzselt könyvtári e-book szolgáltató vállalkozásokat. Ki kell itt emelni, akár Európáról, akár az USA-ról van szó, hogy az e-könyvek kölcsönzésében csak a könyvtár beiratkozott olvasója vehet részt, függetlenül attól, hogy elvileg és gyakorlatilag a világ bármely pontjáról lehetne a könyvet igényelni és természetesen „kölcsönözni”. A licencfeltételek alapján csak beiratkozott olvasó részére adható ki e-könyv a könyvtárak révén. Mi több, az is rögzítve van, hogy csak a könyvtár adott körzetében lakók vehetnek részt az e-kölcsönzésben.

Ma az Egyesült Államok közkönyvtáraiban az elektronikus tartalmak kölcsönzése általános és elfogadott lehetőség a hagyományos print kiadványok szolgáltatása mellett. Európa nagy nyelvű országaiban és a világ más részein is az e-book kölcsönzés (sok más e-tartalommal együtt, mint hangoskönyv, e-tankönyv, digitális játék stb.) meghonosodott.

Az e-book kölcsönzés egy sajátos formáját valósította meg az Amazon. Rendszerén belül a Kindle tulajdonosok, illetve az Amazonon regisztráltak az Amazontól vásárolt könyvek tekintetében élhetnek kölcsönzési lehetőséggel. Azaz egy adott, Amazontól vásárolt könyvet egy olvasó (felhasználó) egy másik, szintén az Amazon rendszerében regisztrált olvasónak kölcsönadhatja, évente meghatározott számban (ez általában 2-3). Ha valaki él a kölcsönadással, természetesen a saját olvasóján nem olvashatja a múvet. Szerzői jogi szerződések alapján ez a konstrukció csak az USA-ban érhető el, illetve azokban az országokban, amelyekre a „Lend me!” szerződés kiterjed. Ez könyvenként és országonként változó.

Szólni kell még az előfizetéses könyvszolgáltatásról is. Vezető képviselője az Oyster és a Scribd. (Az Oyster időközben felfüggesztette a tevékenységét, egyedül a Scribd maradt a piacon, illetve az Amazon Prime konstrukció.) Itt arról van szó, hogy havi vagy évi előfizetésért hozzájuthat az olvasó a szolgáltató teljes könyvkínálatához, beleértve természetesen a leginkább kurrens múveket, sikerlistás darabokat is. A Scribdnél fennáll az olvasó általi feltöltés lehetősége is - ez viszont magával hoz sok jogosulatlan felhasználást. Csak magyar példát említve: Molnár Ferenc és Herczeg Ferenc mûvei is megtalálhatók a Scribden. Ezek még jelenleg nem lejárt szerzői jogú könyvek, hiszen a szerzők halála óta nem telt el hetven év.

\section{E-könyv és a könyvtár (hazai helyzetkép)}

Magyarországon az e-könyv kölcsönzés struktúrája nem épült ki, ennek megfelelően az elektronikus tartalom kölcsönzésére a magyar könyvtárak nem rendezkedtek be. Ez egyáltalán nem jelenti azt, hogy a digitális szolgáltatások területén lemaradásban lenne 
a magyar könyvtárügy más nemzetekhez képest. Kétségtelen tény azonban, hogy az e-könyvhöz való könyvtári viszony eltér néhány tekintetben a nagy nyelvek - elsősorban az angol - jellemezte bibliotékák működési rendszerétől.

Magyarországon az e-könyv vonatkozásában a kölcsönözhetőség helyett az ingyenesség tendenciája és gyakorlata alakult ki. A könyvtár nem időleges használatba adja a múvet, hanem véglegesen letölthetővé teszi az olvasónak. Ez a Magyar Elektronikus Könyvtár metódusa. Tízezernél több magyar és világirodalmi mú magyar változata, illetve nagyszámú magyar alkotás idegen nyelvű verziója érhető el az adatbázisból, regisztráció és más megkötöttség nélkül. Kissé más módszert követ a Digitális Irodalmi Akadémia, amelynek elektronikus könyvespolcairól kortárs magyar szerzők múvei érhetők el online olvasás keretein belül, szintén olvasói identitás megadása nélkül, szabadon. A fenti két nagy állományhoz járulnak még hozzá az egyetemi, szakkönyvtári, megyeivárosi könyvtárak szintén free szöveggyújteményei. Itt sem kell könyvtári tagnak lenni az olvasáshoz. Elmondható tehát, hogy a magyar klasszika és a kortárs szépirodalom egy része szabadon, kötetlenül, platformfüggetlenül elérhető az érdeklődők számára.

Hazai könyvtárakban is folyik az e-könyv elérhetőségekre vonatkozó kísérletezés. Több nagykönyvtárunk helyben olvasásra elérhetővé teszi e-könyv állományát. Az OSZK keretein belül zajlik az ELDORADO projekt, amelynek célja, hogy legálisan, a digitális jogkezelés minden előírását betartva teremtse meg az e-könyvek kölcsönzését a saját rendszerén keresztül. Ezzel olyan platformot hozva létre, amely a hazai kiadók és könyvtárak üzleti együttmúködését lehetővé tenné az e-könyv kölcsönzés kialakítására, fenntartására.

(Ismét hangsúlyozzuk, hogy itt az e-könyvekről adunk képet, nem más könyvtári informatikai szolgáltatásokról, mint például a folyóirat-menedzsmentről, vagy éppen a globális szaktudományos adatbázisok használatáról, vagy szkennelt szöveg-archívumok bemutatásáról.)

Következtetés, hipotézis

A magyar olvasók ismerik és használják az ingyenes e-book-tárakat. Erről meggyőző adatokat láthatunk a MEK - független közremúködők által készített - statisztikájából. Lényegében az a kérdés merül fel: tekintettel arra, hogy a legismertebb magyar klasszikus szépirodalmi szerzők munkái, valamint a kortárs szerzők műveinek reprezentatív válogatása elérhető ingyenesen, kötöttség nélkül, kulturális szempontból és anyagilag érdemes-e a magyar könyvtárakban kiépíteni az e-book-kölcsönzés rendszerét? Megéri-e létrehozni egy olyan szolgáltatást, amely szinte csak a kortárs könyvekre épül? Ha igen: magán- vagy állami források bevonásával? Ez a kérdéskomplexum csakis társadalmi, kultúrpolitikai és természetesen könyvtárszakmai eszmecserék nyomán, pilotprojektek indítása, majd kiértékelése végeztével, az eredmények összegzéseképp kezelhető. Azt viszont feltétlen hangsúlyozni kell, hogy az ingyenes e-book területen meglévő lehetőségeket - még akkor is, ha azok nem az adott könyvtár saját szolgáltatásai - érdemes és szükséges ismertetni, az e-könyvek használatát elősegíteni. 
KEREKES PÁL

\section{Irodalom}

ALLEN, Michael R.: Ez nem hipertext, hanem... (Bekezdések a textualitásról). = Információs Társadalom, 4. évf. 3-4. sz. 2004. 236-251. p.

BALOGH András: Könyvtár, közösségi tér, minőségi-szellemi rekreáció. = Könyv, Könyvtár, Könyvtáros, 24. évf. 1. sz. 2015. 3-14. p.

BÁRTFAI Erika - FEHÉR Péter: Olvassunk! - Digitálisan és/vagy papíron?! Problémák a digitális szövegértés körül. = Létünk, 45. évf. 4. sz. 2015. 121-127. p.

DRAGON Zoltán: Az írás algoritmus foka. = Irodalomismeret, 13. évf. 1. sz. 2014. 64-72. p.

DRÓTOS László: Az e-könyvek technikája [elektronikus könyv]. Budapest, Kossuth Kiadó, 2014. (NÉRO sorozat, 4. füzet) $31 \mathrm{p}$.

GOMBOS Péter - HEVÉRNÉ KANYÓ Andrea - KISS Gábor: A netgeneráció olvasási attitủdje - 14-18 évesek véleménye könyvekről, olvasásról, irodalomról - egy felmérés tanulságai. = Új Pedagógiai Szemle, 65. évf. 1-2. sz. 2015. 52-66. p.

HAJNAL WARD Judit: Piszkos Fred a retinakijelzőn: elektronikus könyvek az amerikai könyvtárakban. = Könyv, Könyvtár, Könyvtáros, 21. évf. 10. sz. 2012. 14-25. p.

HÁHNER Petra: Papír versus képernyő: egyetemi hallgatók és a digitális szövegolvasás. = Információs Társadalom, 14. évf. 4. sz. 2014. 84-94. p.

KEREKES Pál: Változó könyvészeti előképek a digitalizáció szemszögéből: Gutenberg-átértelmezések, avantgard könyvmegújító törekvések e-könyves nézőpontból. = Iskolakultúra, 25. évf. 7-8. sz. 2015. 113-116. p.

KEREKES Pál - KISZL Péter - TAKÁCS Dániel: E-könyvészet: a digitális könyvkultúra alapvonásai. Budapest, ELTE BTK Könyvtár- és Információtudományi Intézet, 2013. 310 p.

KOLTAY Tibor: Jóslatok a könyv és a digitális olvasás jövőjéről. = Könyv, Könyvtár, Könyvtáros, 22. évf. 9. sz. 2013. 6-9. p.

MOLDOVÁN István: Könyvek, e-bookok és digitális könyvtárak: aktuális kérdések és kihívások a könyvtárak előtt. = Könyvtári Levelező/Lap, 24. évf. 11. sz. 2012.3-11.p. Forrás: http:/ [-] epa.oszk.hu/00300/00365/00135/pdf/EPA0365_kll1211_03-11.pdf [2016. január 8.]

NAGY Gyula: Megy-e a digitalizálás által a világ elébb? Avagy mi végre digitalizálunk? = Információs Társadalom, 14. évf. 3. sz. 2014. 44-52. p.

MUZS Krisztina: E-könyvek a könyvtárakban. 1. rész. = Tudományos és Múszaki Tájékoztatás, 62. évf. 1. sz. 2016. 3-26. p.

MUZS Krisztina: E-könyvek a könyvtárban. 2. rész. = Tudományos és Múszaki Tájékoztatás, 63. évf. 2. sz. 2016. 51-64. p.

TÖRTELI TELEK Márta: A digitális szövegek értő olvasása. = Létünk, 45. évf. 4. sz. 2015. 129-137. p.

SIPOS Anna Magdolna: Könyvtári reneszánsz: könyvtárak az információs társadalomban 2.0 [elektronikus könyv]. Budapest, Kossuth kiadó, 2015. (NÉRO sorozat, 13-14. füzet) 111 p.

SZÜTS Zoltán: Irodalom és medialitás: az internetes publikációs paradigma és az online szövegek értelmezésének kérdései. = Irodalomismeret, 13. évf. 1. sz. 2014. 84-88. p.

Kerekes Pál címzetes egyetemi docens az ELTE BTK Könyvtár- és Információtudományi Intézetében. Kutatási területe az elektronikus könyv. 